\title{
ANALISIS FAKTOR- FAKTOR YANG MEMPENGARUHI MINAT MAHASISWA BERWIRAUSAHA \\ (Studi Kasus Mahasiswa Fakultas Ekonomi dan Bisnis Islam IAIN Bengkulu)
}

\author{
Kustin Hartini, SE, MM \\ IAIN Bengkulu \\ kustinhartini@gmail.com
}

\begin{abstract}
The purpose of this study was to determine the effect of entrepreneurship education and family environment on student interest in entrepreneurship. The sampling technique used was purposive sampling. The method of data analysis uses multiple linear analysis with the help of SPSS. From the results of the analysis obtained a regression equation $Y=2.484+0.203 X 1+0.143 X 2$. The equation shows that the coefficients for entrepreneurship education variables and family environment variables have positive signs. This means that if the variable entrepreneurship education or family environment increases, it will encourage an increase in students' interest in entrepreneurship. The $t$ test results for the entrepreneurship education variable are $0.378>0.05$ and for the family environment variable is 0.253>0.05. And the results of the $f$ test produce a significant value of $0.185>0.05$. The t-test and f-test results show that entrepreneurship education variables and family environment variables do not significantly influence student interest in entrepreneurship. Overall the independent variables used in this study were only able to explain the interest in student entrepreneurship by 5.8\% while the remaining $94.2 \%$ was influenced by independent variables not included in the study. This research is expected to be able to further develop educational programs, especially entrepreneurship education, which can motivate students to become entrepreneurs.
\end{abstract}

Keywords: Entrepreneurship education, family environment, interests.

Abstrak : Tujuan dilakukannya penelitian ini adalah untuk mengetahui pengaruh pendidikan kewirausahaan dan lingkungan keluarga terhadap minat mahasiswa untuk berwirausaha. Tehnik pengambilan sampel yang digunakan adalah purposive sampling. Metode analisis data mengunakan analisis linier berganda dengan bantuan SPSS. Dari hasil analisis di peroleh persamaan regresi $Y=2,484+$ 0,203X1 + 0,143X2. Persamaan tersebut menunjukkan bahwa koefisien untuk variable pendidikan kewirausahaan maupun variable lingkungan keluarga mempunyai tanda yang positif. Hal tersebut berarti bahwa jika variable pendidikan kewirausahaan ataupun lingkungan keluarga meningkat maka akan mendorong meningkatnya minat mahasiswa untuk berwirausaha. Hasil Uji $t$ untuk variabel pendidikan kewirausahaan sebesar 0,378>0,05 dan untuk variabel lingkungan keluarga sebesar 0,253 > 0,05. Dan hasil Uji f menghasilkan nilai signifikan 0,185 > 0,05. Hasil Uji t dan Uji f tersebut menunjukkan bahwa variabel pendidikan kewirausahaan dan variabel lingkungan keluarga tidak berpengaruh secara signifikan terhadap minat mahasiswa berwirausaha. Secara keseluruhan variabel bebas yang digunakan dalam penelitian ini hanya mampu menjelaskan minat berwirausaha mahasiswa sebesar 5,8\% sedangkan sisanya sebesar 94,2\% dipengaruhi oleh variabel bebas yang tidak termasuk dalam penelitian. Penelitian ini diharapkan dapat lebih mengembangkan program pendidikan terutama pendidikan kewirausahaan yang dapat mendorong motivasi mahasiswa menjadi seorang wirausaha.

Kata Kunci: Pendidikan kewirausahaan, lingkungan keluarga, minat.

\section{A. PENDAHULUAN}

Negara berkembang adalah
sebuah Negara dengan rata-rata
pendapatan yang rendah, infrastruktur
yang relative terbelakang dan indeks
perkembangan manusia yang kurang
dibandingkan Negara maju. Negara kita
merupakan salah satu contoh Negara

Negara berkembang adalah

yang relative terbelakang dan indeks

perkembangan manusia yang kurang

dibandingkan Negara maju. Negara kita

merupakan salah satu contoh Negara berkembang, Mengapa? Padahal Negara kita dikenal dengan Negara yang kaya akan sumber daya alamnya.

Kecendrungan

Negara-negara

berkembang adalah ditandai dengan

masyarakat yang memiliki pendapatan

perkapita lebih rendah dibandingkan

Negara-negara maju dan biasanya 
memiliki populasi penduduk yang padat. Negara berkembang belum memiliki kondisi ekonomi dan sosial yang makmur, kebanyakan penduduknya miskin, pemikiranpemikiran modern dan kemajuan teknologi belum menyusup sampai kedesa-desa dan banyaknya pengangguran.

Masalah pengangguran dan kemiskinan merupakan masalah yang klasik dan kompleks di Negara kita. Berbagai ahli ekonomi kita dari beberapa periode kepemimpinan pemerintahan selalu memberikan berbagai konsep alternative untuk mengatasi masalah tersebut. Salah satu alternative yang diberikan sebagai upaya untuk mengatasi pengangguran dan kemiskinan adalah dengan memberdayakan masyarakat lewat wirausaha.

Membudayakan berwirausaha dalam masyarakat akan mampu membuka lapangan kerja sehingga dengan terserapnya tenaga kerja akan dapat mengurangi pengangguran. Oleh sebab itu dibutuhkan peran aktif masyarakat dalam upaya meningkatkan kemandirian ekonomi dengan berwirausaha.

Kewirausahaan tidak hanya mampu menciptakan pekerjaan bagi diri sendiri namun mampu melakukan perubahan yang kreatif dalam menghasilkan output yang mampu menjawab kebutuhan masa kini. Dewasa ini kondisi dunia terus mengalami perubahan yang sangat cepat oleh sebab itu dibutuhkan talentatalenta baru dalam dunia kewirausahaan agar mampu bersaing dengan Negaranegara lain. Menurut David Mcclelland ${ }^{1}$, bahwa suatu Negara dapat dikatakan makmur ketika sedikitnya 2\% entrepreneur dari total penduduk yang ada. Kementerian Koperasi dan UKM melansir data olahan BPS dan menyimpulkan adanya pertambahan jumlah pengusaha. Dari sebelumnya $1,6 \%$ menjadi $3,1 \%$ dari populasi. Angka itu menggembirakan karena telah menembus batas psikologis $2 \%$. Jumlah wirausaha di suatu negara kerap dianggap sebagai indikator kemajuan. Patokannya minimal 2\% dari jumlah penduduk harus berprofesi sebagai wirausaha. Dengan jumlah penduduk 250 juta jiwa, negeri ini paling kurang harus memiliki 5 juta jiwa wirausaha. Dibandingkan dengan negara tetangga, harus diakui, kita kalah jumlah. Singapura ada di angka 7\%, Malaysia

1 Thobi Ahmad, Analisis Pengaruh Entrepreneurship Education Terhadap Perilaku Entrepenuer Mahasiswa, Jurnal Gema Aktualita, Vol. 2, No. 1, Juni 2013, hlm. 34 
$5 \%$, Thailand 4,5\%, dan Vietnam 3,3\%.

Amerika dan Jepang sudah melejit jauh.

Sepuluh persen warganya terjun di dunia bisnis. $^{2}$

Populasi wirausaha penting, karena merekalah yang mampu melihat peluang, mengembangkan, dan menciptakan bisnis baru. Alhasil tercipta lapangan kerja dan tumbuhnya perekonomian negara. Terlebih dizaman digital, nyaris tak ada kendala untuk memulai bisnis. Modalnya hanya kreatifitas dan keberanian. Siapapun bisa membuka gerai online, tanpa harus membuka toko fisik terlebih dulu. Makanan, minuman, aplikasi, jasa, apa saja, dsb. Demikian juga promosi dan pemasaran lebih mudah dan cepat dilakukan lewat media sosial. Disisi lain, kalangan muda yang melek internet tidak ragu untuk belanja lewat internet. Fenomena ini mendorong pesatnya pertumbuhan wirausaha di tanah air. ${ }^{3}$ Oleh sebab itu Negara kita sudah seharusnya terus berupaya meningkatkan jumlah pengusahanya dengan menciptakan pengusaha baru yang berkualitas dan terdidik serta memiliki kemampuan kapasitas yang kuat untuk menghadapi persaingan

\footnotetext{
${ }^{2}$ https://nasional.kompas.com/read/2018/ 04/05/17261391. i1/9503
}

yang semakin ketat di era Masyarakat Ekonomi Asean (MEA).

Perguruan tinggi sebagai salah satu lembaga pendidikan yang bertanggung jawab dalam menyiapkan peserta didik menjadi anggota masyarakat yang memiliki kemampuan akademik atau professional yang dapat menerapkan, mengembangkan atau memperkaya khasanah ilmu pengetahuan termasuk pendidikan kewirausahaan.

Menurut Sarwoko pendidikan kewirausahaan perlu diberikan untuk menanamkan nilai inovatif dan kreatif dalam menanggapi peluang, menciptakan peluang serta ketrampilan dan pengetahuan berwirausaha, karena minat berwirausaha merupakan titik awal bagaimana usaha tersebut dijalankan dan bagaimana cara mengelola risiko. Sedangkan Alma menyatakan bahwa pendidikan tinggi yang diperoleh di bangku kuliah diharapkan mampu mengembangkan diri seorang wirausahawan dan bukan sebaliknya yang hanya bisa menunggu lowongan kerja. ${ }^{4}$

Tujuan pendidikan kewirausahaan menurut Adhitama

4 Ni Putu Pebi dan Agung Artha, Pengaruh Sikap, Pendidikan dan Lingkungan Keluarga Terhadap Minat Berwirausaha, E Journal Manajemen Unud, Vol.5, No. 8, 2016, hlm. 5159 
adalah mentransformasikan jiwa, sikap dan perilaku wirausaha dari kelompok business entrepreneur yang dapat menjadi awal untuk merambah lingkungan entrepreneur lainnya, yakni academic, government dan social entrepreneur. ${ }^{5}$ Azwar mengatakan dalam menumbuhkan jiwa kewirausahaan mahasiswa perguruan tinggi merupakan alternatif untuk mengurangi tingkat pengangguran, karena sarjana diharapkan dapat menjadi wirausahawan muda terdidik yang mampu merintis usahanya sendiri agar dapat menjadi daya saing bangsa. ${ }^{6}$

Dalam penelitian Suharti dan Sirine bahwa menumbuhkan jiwa kewirausahaan pada mahasiswa dipercaya merupakan alternatif untuk mengurangi tingkat pengangguran, karena para sarjana diharapkan dapat menjadi wirausaha muda terdidik yang mampu merintis usahanya sendiri ${ }^{7}$. Semua perguruan tinggi di Indonesia telah memasukkan mata kuliah kewirausahaan kedalam kurikulum

5 Ni Putu Pebi dan Agung Artha, Pengaruh Sikap, Pendidikan... hlm. 5159

${ }^{6}$ Azwar dan Budi, Analisis Faktor-faktor yang Mempengaruhi Minat Kewirausahaan, Menara, 12 (1), 2013, hlm 18.

7 Suhartie, Lieli dan Sirine, Hani, Faktor-Faktor yang Berpengaruh Terhadap Minat Kewirausahaan (Entrepreneurial Intention) (Studi Terhadap Mahasiswa Universitas Kristen Satya Wacana, Salatiga), 2011 Jurnal Manajemen Dan Kewirausahaa, Vol.13, No. 2, hlm. 125. sebagai salah satu mata kuliah pokok yang wajib ditempuh oleh semua mahasiswa. Pendidikan kewirausahaan bukannya memberikan landasan teori mengenai konsep tetapi juga harus membentuk sikap, perilaku dan pola pikir seorang wirausahaan ${ }^{8}$.

Intensi berwirausaha mahasiswa yang pernah mendapatkan pendidikan kewirausahaan lebih tinggi dibandingkan mahasiswa yang tidak dan belum pernah mendapatkan pendidikan kewirausahaan. Rata-rata entrepreneurial traits dan entrepreneurial skills mahasiswa yang pernah mendapatkan pendidikan kewirausahaan lebih tinggi dibandingkan mahasiswa yang tidak dan belum pernah mendapatkan pendidikan kewirausahaan. ${ }^{9}$

Selain faktor pendidikan kewirausahaan, pengaruh lingkungan keluarga juga sangat mendorong minat seseorang untuk berwirausaha. Seperti hasil beberapa penelitian terdahulu yang mengatakan bahwa lingkungan

\footnotetext{
${ }^{8}$ Lestari, R.B. dan Wijaya, T, Pengaruh Pendidikan Kewirausahaan Terhadap Minat Berwirausaha Mahasiswa di STIE MDP, STMIK $M D P$, dan STIE MUSI. Jurnal Ilmiah STIE MD, 2012, Vol. 1, No. 2, hlm.113.

9 Silvia, Pengaruh Entrepreneurial Traits Dan Entrepreneurial Skills Terhadap Itensi Kewirausahaan (Studi Empiris Dampak Pendidikan Kewirausahaan pada Mahasiswa Universitas Kristen Petra, Surabaya). 2013, Agora, 1(1): hlm. 17
} 
keluarga berpengaruh secara signifikan pada minat berwirausaha. Dalam penelitian Hisrich dan Peters menemukan bahwa dari 725 wirausahawan yang diteliti mempunyai orang tua atau ayah yang relatif dekat dengan dunia kewirausahaan dan hasil penelitian Cahyono mengemukakan bahwa pekerjaan orang tua berpengaruh signifikan terhadap intensi kewirausahaan ${ }^{10}$. Mahasiswa yang latar belakang keluarga atau saudaranya berwirausaha memiliki tingkat intensi kewirausahaan yang lebih besar dibandingkan mahasiswa yang keluarga atau saudaranya tidak berwirausaha dimana mahasiswa yang keluarganya memiliki usaha telah memiliki pengalaman berwirausaha, sehingga dapat merencanakan karir berwirausaha di masa depan sebagai pilihan hidup. Hal ini menunjukkan bahwa pengalaman usaha dari keluarga akan memberikan pengalaman secara tidak langsung kepada seseorang untuk memiliki minat berwirausaha, karena minimal seseorang atau mahasiswa memiliki pengetahuan bagaimana menjalankan usaha, bagaimana menghadapi masalah dalam usaha, bagaimana memasarkan produk atau

$10 \mathrm{Ni}$ Putu Pebi dan Agung Artha, Pengaruh Sikap, Pendidikan... hlm. 5160 jasa, bagaimana mengakses modal dan sebagainya. $^{11}$

Hasil penelitian Gallyn menyatakan bahwa variabel lingkungan keluarga, sikap mental mahasiswa dan persepsi mahasiswa berwirausaha mempunyai pengaruh positif terhadap minat berwirausaha. ${ }^{12}$ Dalam penilitian lain ditemukan bahwa keluarga menjadi lingkungan yang juga efektif memberikan pengalaman pendidikan kewirausahaan. Namun, hal itu akan tergantung pada latar belakang pekerjaan dan pandangan orang tua terhadap masa depan anak. Latar belakang pekerjaan orang tua yang sebagai pengusaha memang belum dapat dipastikan akan memberikan pandangan kewirausahaan kepada anaknya atau anaknya dilibatkan pada kegiatan kewirausahaan tersebut. Tetapi, secara langsung maupun tidak akan memberikan pandangan dan motivasi kepada anak untuk berwirausaha juga. ${ }^{13}$

${ }^{11}$ Sarwoko dan Endi, Kajian Empiris Entrepreneur Intention Mahasiswa. Jurnal Ekonomi Bisnis, 16(2): hlm:318

${ }^{12}$ Gallyn, Ditya M, , Faktor-faktor yang mempengaruhi Minat Berwirausaha Mahasiswa Universitas Pendidikan Indonesia. Skripsi pada Fakultas Pendidikan Ekonomi dan Bisnis Universitas Pendidikan Indonesia, 2011.

13 Dewi, A.P dan Mulyatiningsih E, Pengaruh Pengalaman Pendidikan Kewirausahaan dan Keterampilan Kejuruan terhadap Motivasi Berwirausaha Siswa, Jurnal Pendidikan Vokasi, 2013, Vol. 3, No. 2. hlm. 238 
Pengalaman orang tua ialah dorongan berupa pendapat terhadap sesuatu berdasarkan pengetahuan dan pengalaman yang dimilikinya yang berguna untuk memberikan masukan sehingga nanti dapat mempengaruhi keputusan yang akan diambil seorang anak. Lingkungan keluarga menurut Lestari adalah jumlah semua benda hidup dan mati serta seluruh kondisi yang ada di dalam kelompok sosial kecil tersebut, yang terdiri atas ayah, ibu dan anak yang mempunyai hubungan sosial karena adanya ikatan darah, perkawinan dan atau adopsi. ${ }^{14}$. Lingkungan keluarga yang dapat mempengaruhi seseorang untuk menjadi wirausaha dapat dilihat dari segi faktor pekerjaan orang tua. Pekerjaan orang tua sering kali terlihat bahwa ada pengaruh dari orang tua yang bekerja sendiri dan memiliki usaha sendiri maka cenderung anaknya akan menjadi pengusaha.

Berdasarkan latarbelakang
diatas dan beberapa hasil-hasil
penelitian sebelumnya maka peneliti
tertarik untuk melakukan penelitian
mengenai "Analisis Faktor-faktor Yang

${ }^{14}$ Lestari, R.B. dan Wijaya, T, Pengaruh Pendidikan Kewirausahaan Terhadap Minat Berwirausaha Mahasiswa di STIE MDP, STMIK $M D P$, dan STIE MUSI. Jurnal Ilmiah STIE MD, 2012, Vol. 1, No. 2, hlm.116.
Mempengaruhi Minat Mahasiswa Berwirausaha"

\section{B. TINJAUAN PUSTAKA DAN HIPOTESIS}

Peter F. Drucker mengatakan bahwa kewirausahaan merupakan kemampuan dalam menciptakan sesuatu yang baru dan berbeda. 15 Kewirausahaan sudah merambah ke dalam dunia pendidikan, diintegrasikan dengan kurikulum di perguruan tinggi. Istilah pendidikan kewirausahaan pun semakin populer di kalangan masyarakat. Menurut Agus Wibowo: "Pendidikan Kewirausahaan merupakan upaya menginternalisasikan jiwa dan mental kewirausahaan baik melalui institusi pendidikan maupun institusi lain seperti lembaga pelatihan, training dan sebagainya"16.

Pendidikan kewirausahaan adalah program pendidikan yang menggarap aspek kewirausahaan sebagai bagian penting dalam pembekalan kompetensi anak didik. Pendidikan kewirausahaan sudah dikembangkan hampir di semua perguruan tinggi di Indonesia dengan proses yang sangat bervariasi yang

\footnotetext{
${ }^{15}$ Kasmir, Kewirausahaan, (Jakarta: PT. Grafindo Persada, 2013). hlm. 20

16 Agus Wibowo, Pendidikan Kewirausahaan (Konsep dan Strategi), (Yogyakarta: Pustaka Pelajar, 2011). hlm. 30
} 
bertujuan untuk menciptakan wirausaha ${ }^{17}$.

Saat ini beberapa perguruan tinggi, salah satunya di IAIN Bengkulu, menyediakan mata kuliah kewirausahaan sebagai mata kuliah wajib yang harus diikuti oleh semua mahasiswa Fakultas Ekonomi dan Bisnis Islam. Perguruan tinggi dalam hal ini memiliki pemahaman bahwa pendidikan kewirausahaan bukanlah pendidikan usaha, sehingga dapat dipelajari oleh semua mahasiswa dari berbagai bidang ilmu. Pendidikan kewirausahaan merupakan pendidikan dan pelatihan yang memungkinkan mahasiswa untuk mengembangkan dan menggunakan kreativitas mereka, mengambil inisiatif, tanggung jawab dan risiko. Dengan demikian, pendidikan kewirausahaan bukan pendidikan usaha (enterprise education) sehingga pendidikan kewirausahaan tidak hanya berfokus pada bisnis. (UNISCO, 2008). ${ }^{18}$

Pendidikan kewirausahaan di Perguruan Tinggi bukan berarti pendidikan untuk membuka usaha (bisnis), melainkan harus dimaknai

17 Muhammad Saroni, Mendidik dan Melatih Etrepreneur Muda, (Yogyakarta: Ar Ruzz Media). hlm. 45

18 Susilaningsih, Pendidikan Kewirausahaan di Perguruan Tinggi, Jurnal Economia, 2015, Vol. 11, No. 1, hlm. 4 sebagai pendidikan untuk membangun karakter wirausaha, pola pikir wirausaha, dan perilaku wirausaha. Output pendidikan kewirausahaan di perguruan tinggi dapat menjadi entrepreneur atau business entrepreneur dan intrapreneur sebagai academic entrepreneur, corporate entrepreneur maupun social entrepreneur. Oleh karena wirausaha dapat ditemukan pada berbagai bidang/profesi, maka seseorang yang memiliki perilaku wirausaha dapat berada pada perusahaan yang didirikan dan dikelola sendiri, sebagai entrepreneur, atau pada perusahaan/organisasi lainnya, sebagai intrapreneur. Intrapreneur adalah mereka yang bertanggungjawab untuk melakukan inovasi dalam organisasi ${ }^{19}$.

Pendidikan kewirausahaan di perguruan tinggi di Indonesia sangat bervariasi, demikian juga pendidikan kewirausahaan diberbagai perguruan tinggi di beberapa negara. Pendidikan kewirausahaan di Singapore dikembangkan dalam menghadapi globalisasi knowledge economy, dengan menggunakan strategi knowledge based pada pertumbuhan ekonominya. Melalui strategi ini terjadilah transisi

\footnotetext{
Susilaningsih, Pendidikan Kewirausahaan di Perguruan.... hlm. 5
} 
dari investment-driven economy menuju innovation-driven economy, dengan menekankan pada pembangunan intellectual capital dan komersialisasinya untuk menciptakan value dan pekerjaan. Pada masa transformasi ekonomi ini peran perguruan tinggi semakin nyata dalam menstimulasi pertumbuhan ekonomi melalui penelitian yang relevan dengan kebutuhan industri, komersialisasi teknologi, mengembangkan high-tech, menarik individu berbakat dari luar negeri, dan menanamkan mindset kewirausahaan kepada para sarjana. ${ }^{20}$

National University of Singapore (NUS) pada akhir tahun 1990an menerapkan model entrepreneurial university, dan agar universitas menjadi lebih entrepreneurial maka didirikanlah NUS Enterprise. NUS Enterprise berinistiatif untuk mereformasi kebijakan-kebijakan komersialisasi teknologi, dan menanamkan elemen kewirausahaan yang kuat pada pendidikan dan penelitian. Berbeda dengan pendidikan kewirausahaan di Singapore, di China pendidikan kewirausahaan di perguruan tinggi lebih ditekankan pada penciptaan business entrepreneur. Setiap tahun secara bergantian universitasuniversitas menyelenggarakan kompetisi Business Plan Nasional yang diikuti oleh mahasiswa dari hampir semua perguruan tinggi di China. Beberapa universitas memiliki inkubator untuk memfasilitasi mahasiswa yang memulai usaha. Di setiap kota, tersedia inkubator yang disediakan untuk wirausaha-wirausaha muda. Inkubator-inkubator ini didirikan oleh organisasi-organisasi pemerintah dan memberikan pelayanan kepada wirausaha dengan harga yang layak. Beberapa perusahaan menengah memfasilitasi kegiatan-kegiatan wirausaha. China memiliki lingkungan kewirausahaan yang mendukung. Para orang tua memiliki pemikiran yang luas, mereka mendukung anak-anak mereka untuk membuka usaha, mereka memberi bantuan keuangan, berbagi pengalaman bisnis dan network. Bahkan, ketika anak-anak mereka tidak berhasil pada kesempatan pertamanya, para orang tua masih berpikir bahwa itu adalah pengalaman yang baik yang akan membantu masa depan karier anak-anaknya. Semua ini menimbulkan adanya kebutuhan terhadap pendidikan

\footnotetext{
Susilaningsih, Pendidikan

Kewirausahaan di Perguruan.... hlm. 5
} 
kewirausahaan yang baik di perguruan tinggi $^{21}$.

Hubungan orang tua secara umum sangat besar pengaruhnya terhadap perkembangan anak. Pekerjaan orang tua merupakan faktor pembentuk kewirausahaan seseorang. Orang tua akan cenderung menginginkan anaknya lebih sukses dari orang tuanya. Orang tua akan mengajarkan kepada anaknya berdasarkan latar belakang yang dimiliki orang tuanya. Latar belakang orang tua yang berwirausaha mempunyai pengaruh yang signifikan terhadap intensi berwirausaha anak. Hasil penelitian Sumarsono menemukan secara regresi sederhana tidak ada perbedaan antara orang yang memiliki latar belakang wirausaha dengan orangtua yang bukan wirausaha terhadap minat berwirausaha. Secara parsial hasil penelitiannya bahwa lingkungan dan pendidikan tidak berpengaruh secara signifikan terhadap minat berwirausaha. ${ }^{22}$

Minat adalah kesungguhan niat seseorang untuk melakukan perbuatan

$21 \quad$ Susilaningsih, Pendidikan
Kewirausahaan di Perguruan.... hlm. 6

${ }^{22}$ Sumarsono, Hadi, Faktor-Faktor yang Mempengaruhi Intensi Wirausaha Mahasiswa Universitas Muhammadiyah Ponogoro, Jurnal Manajemen,2013, Vol. 11. No. 2, hlm. 81 atau memunculkan suatu perilaku tertentu. Maka minat kewirausahaan dapat diartikan sebagai niat atau keinginan yang ada pada diri seseorang untuk melakukan suatu tindakan wirausaha. $^{23}$

Minat merupakan variable antara yang menyebabkan terjadinya perilaku dan suatu sikap atau variable lainnya. Dari tinjauan pustaka, maka hipotesis yang diajukan dalam penelitian ini adalah:

H1: Secara persial minat mahasiswa berwirausaha signifikan dipengaruhi oleh pendidikan kewirausahaan.

H2: Secara parsial minat mahasiswa berwirausaha signifikan dipengaruhi oleh lingkungan keluarga.

H3: Secara simultan minat mahasiswa berwirausaha signifikan dipengaruhi oleh pendidikan kewirausahaan dan lingkungan keluarga.

\section{METODOLOGI PENELITIAN}

Tehnik pengambilan sampel yang digunakan adalah purposive sampling yaitu tehnik penentuan sampel dengan pertimbangan tertentu.

\footnotetext{
${ }^{23}$ Sumarsono, Hadi, Faktor-Faktor yang
} Mempengaruhi Intensi..... hlm. 67. 
Penelitian ini mengunakan data primer dengan menyebar kuisioner.

Tehnik pengukuran dengan mengunakan skala Likert. Kuesioner diolah dengan melakukan uji validitas dan uji reliabilitas terlebih dahulu.

Metode yang digunakan dalam penelitian ini adalah dengan mengunakan analisis linier berganda dengan bantuan program aplikasi SPSS. Analisis ini untuk menguji pengaruh pendidikan kewirausahaan dan lingkungan keluarga terhadap minat mahasiswa berwirausaha.

Persamaan regresi linier berganda adalah ${ }^{24}$ :

$$
\begin{gathered}
\mathrm{Y}=\mathrm{a}+\mathrm{b}_{1} \mathrm{X}_{1}+\mathrm{b}_{2} \mathrm{X}_{2} \\
\mathrm{Y}=\text { Minat } \\
\mathrm{a}=\text { Konstanta } \\
\mathrm{b}_{1} \mathrm{~b}_{2}=\text { Koefisien regresi } \\
\mathrm{X}_{1}=\text { Pendidikan kewirausahaan } \\
\mathrm{X}_{2}=\text { Lingkungan Keluarga }
\end{gathered}
$$

\section{HASIL DAN PEMBAHASAN}

\section{Deskripsi Responden}

Responden yang menjadi
obyek penelitian ini adalah
mahasiswa yang masih tercatat
sebagai mahasiswa yang aktif di
Fakultas Ekonomi dan Bisnis Islam
IAIN Bengkulu. Jumlah responden

${ }^{24}$ Sugiyono, Metode Penelitian Bisnis Pendekatan Kuantitatif, Kualitatif, dan $R \& D$, ( Bandung: Alfabeta, 2014). hlm. 276 yang di teliti ada 60 responden. Berdasarkan data yang diperoleh dari karakteristik responden, responden terdiri dari tiga angkatan.

Berdasakan persentasi jurusan, responden terdiri dari jurusan Ekonomi Islam 43,3\% dan jurusan Perbankan Syariah 56,7\%. Responden didominasi oleh perempuan sebesar $86,7 \%$ dan lakilaki $13,3 \%$ dan ini artinya bahwa perempuan yang dominan pengaruhnya dalam penelitian ini. Berdasarkan pekerjaan orang tua, bahwa $31,7 \%$ pekerjaan orang tua dari responden adalah tani dan lainlain. Sementara $25 \%$ pekerjaannya adalah wirausaha, $10 \%$ PNS, dan $1,7 \%$ pekerjaan orangtua responden adalah nelayan. Terkait dengan penelitian ini berarti bahwa hanya $25 \%$ pekerjaan orang tua responden berprofesi sebagai wirausaha.

\section{Pengujian Validitas dan}

\section{Reliabilitas}

Instrument yang valid berarti alat ukur yang digunakan untuk mendapatkan data (menukur) data itu valid. Valid itu berarti instrument tersebut dapat digunakan untuk mengukur apa yang hendak diukur. Penelitian ini mengunakan uji validitas Product Momen Pearson 
Correlation yang digunakan sebagai dasar pengambilan keputusan. Dimana jika diperoleh nilai $\mathrm{r}$ hitung $>\mathrm{r}$ tabel maka instrument tersebut dapat dinyatakan valid. Uji reliabilitas adalah uji yang dipakai untuk menunjukkan keterhandalan atau tidaknya suatu kuesioner. ${ }^{25}$

\section{a. Uji Validitas}

Berdasarkan pada hasil analisis pengujian validitas Product Momen Pearson Correlation dengan mengunakan alat bantu program aplikasi SPSS untuk masing-masing intrumen maka dapat disimpulkan bahwa instrumen yang digunakan dalam penelitian ini valid. Hal ini ditunjukan dalam tabel. 1. hasil uji validitas instrumen dengan nilai dari keseluruhan $r$ hitung untuk setiap instrument lebih besar dari nilai $r$ tabel. Nilai $r$ tabel untuk $\mathrm{N}=60$ dengan taraf signifikan 5\% adalah 0,254.

Tabel. 1. Hasil uji validitas

\section{Instrumen}

\begin{tabular}{|c|c|c|}
\hline Instrument & r Hitung & r Tabel \\
\hline PK1 & 0,308 & 0,254 \\
\hline PK2 & 0,441 & 0,254 \\
\hline PK3 & 0,498 & 0,254 \\
\hline
\end{tabular}

25 Sugiyono,Metode Penelitian Bisnis Pendekatan Kuantitatif, Kualitatif, dan $R \& D$. Bandung: Alfabeta, 2014

\begin{tabular}{|c|l|l|}
\hline PK4 & 0,373 & 0,254 \\
\hline PK5 & 0,742 & 0,254 \\
\hline PK6 & 0,706 & 0,254 \\
\hline PK7 & 0,557 & 0,254 \\
\hline PK8 & 0,719 & 0,254 \\
\hline PK9 & 0,529 & 0,254 \\
\hline PK10 & 0,626 & 0,254 \\
\hline PK11 & 0,487 & 0,254 \\
\hline PK12 & 0,684 & 0,254 \\
\hline PK13 & 0,569 & 0,254 \\
\hline LK1 & 0,946 & 0,254 \\
\hline LK2 & 0,908 & 0,254 \\
\hline LK3 & 0,864 & 0,254 \\
\hline $\mathrm{N}$ & 1,000 & 0,254 \\
\hline
\end{tabular}

Sumber: Data diolah 2018

\section{b. Uji Reliabilitas}

Hasil analisis pengujian reliabilitas Alpha Cronbanch's dengan SPSS dapat ditarik kesimpulan bahwa untuk keseluruhan instrument yang digunakan dalam penelitian dinyatakan reliabel. Hal ini ditunjukan dengan nilai Crobanch's Alpha sebesar 0,838 yang lebih besar dari $r$ tabel ( 0,254) , seperti terlihat dalam tabel 2.

\section{Tabel. 2. Hasil uji reliabilitas}

\section{instrument}

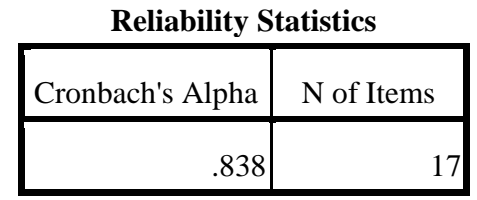

Item-Total Statistics 


\begin{tabular}{|c|c|c|c|c|}
\hline & $\begin{array}{l}\text { Scale Mean if } \\
\text { Item Deleted }\end{array}$ & $\begin{array}{c}\text { Scale } \\
\text { Variance if } \\
\text { Item Deleted }\end{array}$ & $\begin{array}{l}\text { Corrected } \\
\text { Item-Total } \\
\text { Correlation }\end{array}$ & $\begin{array}{c}\text { Cronbach's } \\
\text { Alpha if Item } \\
\text { Deleted }\end{array}$ \\
\hline PK1 & 51.50 & 30.729 & .096 & .84 \\
\hline PK2 & 51.52 & 29.678 & .352 & .834 \\
\hline PK3 & 51.55 & 30.014 & .316 & .835 \\
\hline PK4 & 51.43 & 30.792 & .176 & .840 \\
\hline PK5 & 51.43 & 26.250 & .745 & .812 \\
\hline PK6 & 51.57 & 28.351 & .642 & .822 \\
\hline PK7 & 51.10 & 28.159 & .442 & .829 \\
\hline PK8 & 51.68 & 25.881 & .614 & .818 \\
\hline PK9 & 51.57 & 28.724 & .298 & .83 \\
\hline PK10 & 51.08 & 28.010 & .541 & .82 \\
\hline PK11 & 51.17 & 28.040 & .445 & .829 \\
\hline PK12 & 51.53 & 27.914 & .557 & .823 \\
\hline PK13 & 51.12 & 28.308 & .494 & .827 \\
\hline LK1 & 51.17 & 26.853 & .595 & .820 \\
\hline LK2 & 51.28 & 27.529 & .503 & .826 \\
\hline LK3 & 51.15 & 28.062 & .461 & .828 \\
\hline Minat & 50.95 & 30.082 & .226 & .839 \\
\hline
\end{tabular}

Sumber: Data diolah 2018

\section{Analisis Regresi Berganda}

Analisis data dilakukan dengan bantuan program aplikasi SPSS diperolah persamaan regresi sebagai berikut:

$$
\mathrm{Y}=2,484+0,203 \mathrm{X} 1+0,143 \mathrm{X} 2
$$

Persamaan diatas diambil berdasarkan nilai Beta (Standardized Coefficients) yang ada pada tabel.3 yang dihasilkan dari analisis regresi. Persamaan tersebut menunjukkan bahwa koefisien untuk variable pendidikan kewirausahaan maupun variable lingkungan keluarga mempunyai tanda yang positif. Hal tersebut berarti bahwa jika variable pendidikan kewirausahaan ataupun lingkungan keluarga meningkat maka akan mendorong meningkatnya minat mahasiswa untuk berwirausaha.

Tabel. 3. Hasil analisis regresi

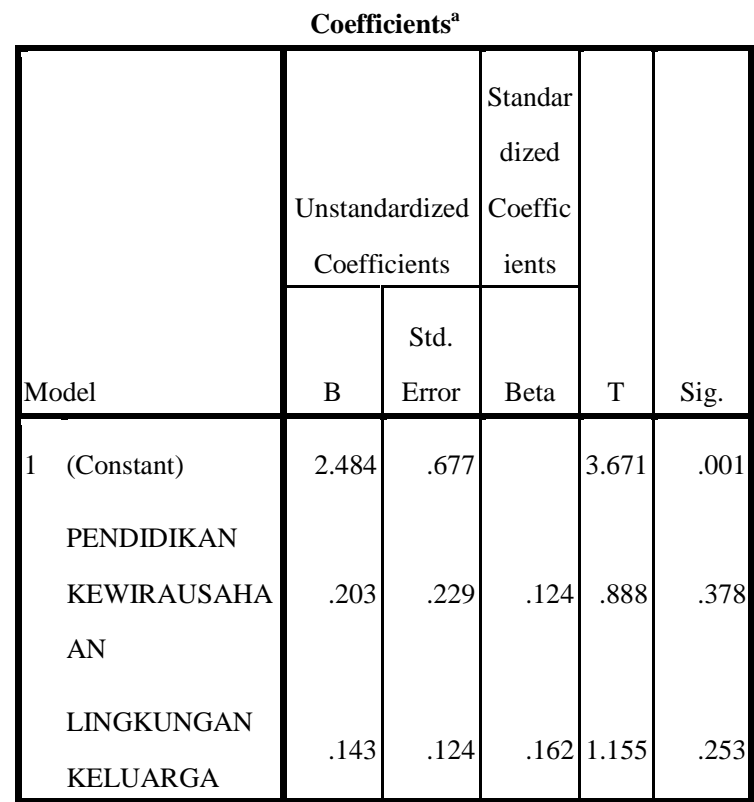

a. Dependent

Variable: MINAT

Sumber: Data diolah 2018

\section{a. Uji T (t-test)}

Pengujian hipotesis dengan t-test dilakukan dengan membandingkan nilai probabilitas (sign) dengan nilai alpha yang sudah ditetapkan dalam penelitian ini yaitu sebesar 5\% (0.05). Jika hasilnya lebih kecil dari nilai alpha 0,05 maka manunjukkan 
tidak ada pengaruh yang signifikan.

\section{1) Pengaruh Pendidikan \\ Kewirausahaan terhadap minat berwirausaha}

Dari hasil analisis dengan mengunakan SPSS seperti terlihat dalam tabel. 3 dapat diketahui bahwa nilai probabilitas (sign) untuk variable pendidikan kewirausahaan adalah 0,378 yang nilainya lebih besar dari alpha $0,05(0,378>0,05)$ dan ini artinya tidak ada pengaruh yang signifikan dari variable pendidikan kewirausahaan dengan minat mahasiswa berwirausaha sehingga hipotesis pertama $(\mathrm{H} 1)$ ditolak. Hal ini menunjukkan bahwa pendidikan kewirausahaan hanya sebatas memberikan pemahaman kepada mahasiswa belum mengarah kepada dorongan untuk melakukan wirausaha. Hasil penelitian ini didukung oleh penelitian yang telah dilakukkan oleh Lielie Suharti dan Hani Sirine yang tidak ditemukannya pengaruh yang signifikan antara tingkat keikutsertaan mahasiswa dalam kegiatan pendidikan kewirausahaan dengan niat kewirausahaan mahasiswa. Dalam hal ini kemungkinan disebabkan oleh sistem pembelajaran mata kuliah pendidikan kewirausahaan yang persentase teorinya lebih dibandingkan dengan prakteknya. Beberapa penelitian terdahulu menunjukkan ada pengaruh pendidikan kewirausahaan dengan minat mahasiswa menjadi wirausaha itu disebabkan salah satunya adalah persentase praktek wirausaha lebih besar dibandingkan dengan teorinya. Ada banyak perbedaan sistem pendidikan di negara kita, dalam hal ini pendidikan kewirausahaan dengan negara lain. Di China pendidikan kewirausahaan di perguruan tinggi lebih ditekankan pada penciptaan business entrepreneur. Setiap tahun secara bergantian universitasuniversitas menyelenggarakan kompetisi Business Plan Nasional yang diikuti oleh mahasiswa dari hampir semua 
perguruan tinggi di China.

responden yang

Beberapa universitas memiliki

mengidentifikasikan latar

inkubator untuk memfasilitasi

belakang pekerjaan orangtua

mahasiswa yang memulai

sebagai wirausaha hanya

usaha. Di setiap kota, tersedia

inkubator yang disediakan

untuk wirausaha-wirausaha

muda. Inkubator-inkubator ini

didirikan oleh organisasi-

organisasi pemerintah dan

memberikan pelayanan kepada

wirausaha dengan harga yang

layak. Beberapa perusahaan

menengah memfasilitasi

kegiatan-kegiatan wirausaha.

\section{2) Pengaruh Lingkungan}

\section{Keluarga terhadap minat}

\section{berwirausaha}

Pengujian hipotesis untuk variable lingkungan keluarga, dari hasil analisis diperoleh nilai probabilitas (sign) sebesar 0,253 dan nilai tersebut lebih besar dari alpha $0,05(0,253$ > 0.05). Dan ini berarti bahwa variable lingkungan keluarga tidak berpengaruh secara signifikan terhadap minat mahasiswa berwirausaha sehingga hipotesis kedua (H2) juga ditolak. Hasil penelitian ini didorong oleh adanya temuan dari jawaban berwirausaha terbentuk ketika ada dorongan dan dukungan positif dari keluarga. Anak yang memiliki orang tua sebagai pengusaha atau tumbuh di lingkungan keluarga yang wirausahawan akan mendapatkan pengetahuan lebih tentang berwirausaha sehingga akan memebentuk sikap dan persepsi yang bisa berpengaruh pada minat.

Penelitian ini mendukung penelitian yang dilakukan oleh Afif Nur Rahmadi dan Budi H serta penelitian Vivi Setyowati yang menunjukkan bahwa lingkungan keluarga tidak berpengaruh secara signifikan terhadap minat mahasiswa berwirausaha.

\section{b. Uji F (f-test)}

Uji f-test digunakan untuk mengetahui seberapa jauh pengaruh variable pendidikan kewirausahaa dan lingkungan keluarga yang dirasakan secara simultan pada minat mahasiswa 
berwirausaha. Dari hasil analisis data seperti terlihat dalam tabel. 4 dapat diketahui nilai probabilitas (sign) sebesar 0,185 yang lebih besar dari nilai alpha $0,05(0,185$ $>0,05)$ ini berarti bahwa secara simultan variable pendidikan kewirausahaan dan lingkungan keluarga dirasakan tidak berpengaruh secara signifikan terhadap minat mahasiswa menjadi wirausaha.

Tabel. 4. Hasil uji F (f-test)

\begin{tabular}{|c|c|c|c|c|c|}
\hline \multicolumn{6}{|c|}{ ANOVA $^{b}$} \\
\hline Model & $\begin{array}{l}\text { Sum of } \\
\text { Squares }\end{array}$ & Df & $\begin{array}{c}\text { Mean } \\
\text { Square }\end{array}$ & $\mathrm{F}$ & Sig. \\
\hline 1Regression & 1.058 & 2 & .529 & 1.739 & $.185^{\circ}$ \\
\hline Residual & 17.342 & 57 & .304 & & \\
\hline Total & 18.400 & 59 & & & \\
\hline
\end{tabular}

a. Predictors: (Constant), LINGKUNGAN KELUARGA,

PENDIDIKAN KEWIRAUSAHAAN

b. Dependent Variable:

MINAT

Sumber: Data diolah 2018

\section{c. Uji Koefisien Determinasi $\left(\mathbf{R}^{\mathbf{2}}\right)$}

Uji $\mathrm{R}^{2}$ digunakan untuk menghitung besarnya kontribusi variable bebas terhadap variable terikat. Dari hasil analisis seperti dalam tabel. 5 diperoleh nilai koefisien determinasi $\left(\mathrm{R}^{2}\right)$ sebesar 0,058 artinya kemampuan variable bebas pendidikan kewirausahaan dan lingkungan keluarga dalam menjelaskan variable terikat minat mahasiswa menjadi wirausaha hanya sebesar $5,8 \%$ sedangkan sisanya sebesar $94,2 \%$ dipengaruhi oleh variable bebas yang tidak termasuk dalam penelitian ini.

Tabel. 5. Hasil uji koefisien determinasi $\left(\mathbf{R}^{2}\right)$

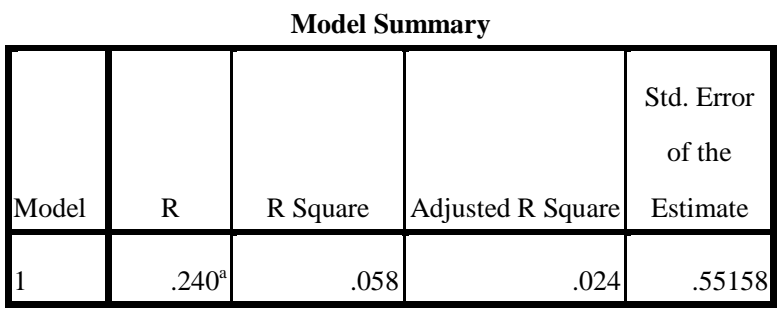

a. Predictors: (Constant), LINGKUNGAN KELUARGA,

PENDIDIKAN KEWIRAUSAHAAN

Sumber: Data diolah 2018

Berdasarkan hasil pengujian hipotesis dengan mengunakan analisis regresi berganda diperoleh hasil bahwa variable pendidikan kewirausahaan dan variable lingkungan keluarga tidak berpengaruh secara signifikan terhadap minat mahasiswa menjadi wirausaha hal ini ditunjukkan dengan nilai $r$ hitung lebih besar dari $\mathrm{r}$ tabel. Begitu juga dengan analisis secara simultan bahwa minat mahasiswa menjadi wirausaha tidak dipengaruhi oleh pendidikan kewirausahaan dan lingkungan keluarga. 
Hasil penelitian ini sejalan dengan penelitian yang dilakukan oleh Dassal \& Abraham (2012) mengenai factor-faktor yang mempengaruhi minat berwirausaha. Dan hasil penelitiannya menunjukkan bahwa variable kepercayaan diri dan resiko secara parsial berpengaruh positif dan signifikan terhadap minat berwirausaha sedangkan pengetahuan (pendidikan kewirausahaan) dan modal secara parsial berpengaruh posistif tetapi tidak signifikan terhadap minat berwirausaha. Begitu juga dengan hasil penelitian Saraswati dkk (2014) Dosen Fakultas Ekonomi Merdeka Madiun terkait factorfaktor yang mempengaruhi minat mahasiswa berwirausaha menyatakan bahwa dukungan akademik tidak berpengaruh secara signifikan terhadap minat mahasiswa berwirausaha.

Berbeda dengan beberapa penelitian terdahulu seperti penelitian yang dilakukan oleh Retno Budi dkk (2012) yang melakukan di tiga universitas dan hasil penelitiannya menyatakan bahwa pendidikan kewirausahaan bepengaruh secara signifikan terhadap minat mahasiswa berwirausaha. Penelitian Eka Aprilianti (2012) juga menunjukkan bahwa kepribadian wirausaha, pendidikan kewirausahaan dan lingkungan keluarga, masing-masing mempunyai pengaruh yang signifikan terhadap minat berwirausaha.

\section{E. KESIMPULAN DAN SARAN}

Berdasarkan hasil analisis dan pembahasan yang telah diuraikan diatas maka dapat ditarik beberapa kesimpulan:

1. Pendidikan kewirausahaan tidak berpengaruh signifikan te rhadap minat mahasiswa menjadi wirausaha.

2. Lingkungan keluarga tidak berpengaruh secara signifikan terhadap minat mahasiswa menjadi wirausaha

3. Pendidikan kewirausahaan dan lingkungan keluarga secara simultan tidak berpengaruh signifikan terhadap minat mahasiswa menjadi wirausaha.

Dengan demikian kami selaku peneliti memberikan saran sebagai berikut:

1. Fakultas Ekonomi dan Bisnis Islam IAIN Bengkulu diharapkan dapat 
lebih mengembangkan program pendidikan terutama pendidikan kewirausahaan yang dapat mendorong motivasi mahasiswa menjadi seorang wirausaha (entrepreneur) dengan peningkatan prosentase praktikum kewirausahaan dan membuka lebih banyak mata kuliah entrepreneurship sehingga mahasiswa semakin paham akan pentingnya entrepreneur dan bagaimana menjadi seorang entrepreneur.

2. Penelitian ini tidak terlepas dari keterbatasan. Pengelolaan data yang tidak terlalu mendalam baik untuk pendidikan kewirausahaan maupun lingkungan keluarga. Pada penelitian selanjutnya diharapkan dapat membahasnya secara mendalam.

\section{DAFTAR PUSTAKA}

Adhitama, Paulus Patria, 2014, FaktorFaktor yang Mempengaruhi Minat Berwirausaha (Studi Kasus Mahasiswa Fakultas Ekonomi dan Bisnis UNDIP, Semarang), Skripsi Sarjana Jurusan Pendidikan Ekonomi Fakultas Diponogoro, Semarang.

Afif Nur Rahmadi dan Budi Heryanto, 2016, Analisis Faktor-faktor yang Mempengaruhi Minat Mahasiswa Berwirausaha Pada Mahasiswa prodi Manajemen Fakultas Ekonomi Universitar Kadari, Jurnal Ekonomi Universitas Kadari, Vol. 1, No. 2.
Alma, Buchari, 2007, Kewirausahaan, Bandung: Alfabeta.

Andika, Manda dan Iskandarsyah Madjid, 2012, Analisis Pengaruh Sikap, Norma Subjektif, dan Efikasi Diri terhadap Intensi Berwirausaha pada Mahasiswa Fakultas Ekonomi Universitas Syiah Kuala: Studi Pada Mahasiswa Fakutas Ekonomi Universitas Syiah Kuala. Disampaikan pada Seminar EcoEntrepreneurship Seminar \& Call for Paper "Improving Performance by Improving Environment" 2012 Fakultas Ekonomi, Universitas Negeri Semarang, 14-15 Maret 2012.

Astuti, Titiek Puji dan Pujianto, 2014, Pengaruh Faktor Demografi, Psikologis dan Kontekstual terhadap Niat Kewirausahaan pada Mahasiswa (Studi terhadap Mahasiswa Universitas Setia Budi Surakarta), Disampaikan pada Seminar Nasional dan Call For Paper Program Studi Akuntansi FEB UMS dengan tema Manajemen dan Ekonomi, 25 Juni 2014.

Azwar, Budi, 2013, Analisis Faktor-faktor yang Mempengaruhi Niat Kewirausahaan (Entrepreneurial Intention), Studi Terhadap Mahasiswa Universitas Islam Negeri SUSKA Riau. Menara, vol.12. No.1.

Badan Perencanaan Pembangunan Nasional (BAPPENAS), 2009, Angka Pengangguran Akademik Lebih dari Dua Juta. Jakarta.www.bappenas.go.id.

Badan Pusat Statistik (BPS), 2011, Pengganguran Berdasarkan Tingkat Pendidikan 20062010.www.bps.go.id.

Cahyono, Andi, 2010, Faktor-Faktor Yang Mempengaruhi Intensi Kewirausahaan Mahasiswa Program 
Manajemen Bisnis Fakultas Ekonomi Universitas Kristen Petra Tahun 2006-2009, http://dewey.petra.ac.id/jiunkpe_dg 16679

Chimucheka, Tendai,2013, The Impact of Entrepreneurship Education on the Establishment and Survival of Small, Micro and Medium Enterprises (SMMEs), Journal Economics, Vol. 4. No. 2.

Dewi, A.P dan Mulyatiningsih E, 2013, Pengaruh Pengalaman Pendidikan Kewirausahaan dan Keterampilan Kejuruan terhadap Motivasi Berwirausaha Siswa, Jurnal Pendidikan Vokasi, Vol. 3. No. 2.

Frazier,B \& Niehm, L.S, 2008, FCS Students' Attitudes and Intentions Toward Entrepreneurial Careers. Journal of Family and Consumer Sciences, 100(2), April 2008, Academic Research Library.

Gallyn, Ditya M, 2011, Faktor-faktor yang mempengaruhi Minat Berwirausaha Mahasiswa Universitas Pendidikan Indonesia. Skripsi pada Fakultas Pendidikan Ekonomi dan Bisnis Universitas Pendidikan Indonesia.

https://nasional.kompas.com/read/2018/04/ 05/17261391/jumlah-entrepreneurdi-indonesia-jauh-di-bawah-negaramaju-ini-kata-jokowi

https://www.kominfo.go.id/content/detail/ 9503/peluang-besar-jadi-pengusahadi-era-digital/0/berita

Kasmir, 2013, Kewirausahaan, Edisi 8, Edisi Revisi, Rajawali Pers, Jakarta.

Kimiyaei, Ali, Abbas Gholami, Abbas Safari, dan Ali Shirpour, 2015, Entrepreneurship Education and Entrepreneurial School a New Approach in Education and the Growth of Students, Jurnal UMP Social Sciences and Technology Management, Vol. 3. No.3.
Lestari, R.B. dan Wijaya, T, 2012, Pengaruh Pendidikan Kewirausahaan Terhadap Minat Berwirausaha Mahasiswa di STIE MDP, STMIK MDP, dan STIE MUSI. Jurnal Ilmiah STIE MD, Vol. 1. No. 2.

Mopangga, Herwin, 2014, Faktor Determinan Minat Wirausaha Mahasiswa Fakultas Ekonomi dan Bisnis Universitas Negeri Gorontalo, Trikonomika, Vol. 13. No.1.

Putra, Rano Aditya, 2012, Faktor-Faktor Penentu Minat Mahasiwa Manajemen Untuk Berwirasusaha (Studi Mahasiswa Manajemen FE Universitas Negeri Padang).

Rochayati, Umi et al., 2013, Pengaruh Faktor Sosiodemografi, Sikap, dan Kontekstualterhadap Niat Berwirausaha Siswa. Jurnal Kependidikan, Vol. 43. No. 2.

Rosmiati, Rosmiati., Teguh Santosa, Junias., Munawar, Munawar, 2015, Sikap, Motivasi dan Minat Berwirausaha Mahasiswa, Jurnal Manajemen Dan Kewirausahaan, Vol. 17. No. 1.

Sarwoko, Endi, 2011, Kajian Empiris Entrepreneur Intention Mahasiswa, Jurnal Ekonomi Bisnis, Vol. 16. No.

Sarwoko, Endi, 2011, Kajian Empiris Entrepreneur Intention Mahasiswa. Jurnal Ekonomi Bisnis, Vol. 16. No. 2.

Silvia, 2013, Pengaruh Entrepreneurial Traits Dan Entrepreneurial Skills Terhadap Itensi Kewirausahaan (Studi Empiris Dampak Pendidikan Kewirausahaan pada Mahasiswa Universitas Kristen Petra, Surabaya). Agora, Vol.1. No.1.

Sugiyono, 2014, Metode Penelitian Bisnis Pendekatan Kuantitatif, Kualitatif, dan $R \& D$. Bandung: Alfabeta. 
Suhartie, Lieli dan Sirine, Hani, 2011, Faktor-Faktor yang Berpengaruh Terhadap Niat Kewirausahaan (Entrepreneurial Intention) (Studi Terhadap Mahasiswa Universitas Kristen Satya Wacana, Salatiga), Jurnal Manajemen Dan Kewirausahaan, Vol.13. No. 2.

Suhartini, Yati, 2011, Analisis FaktorFaktor yang Mempengaruhi Minat Mahasiswa Dalam Berwirausaha (Studi Pada Mahasiswa Universitas PGRI Yogyakarta), AKMENIKA UPY. Vol. 9. No. 10.

Sumarsono, Hadi, 2012, Faktor-Faktor yang Mempengaruhi Intensi Wirausaha Mahasiswa Universitas Muhammadiyah Ponogoro, Jurnal Manajemen, Vol. 11. No. 2.

Susilaningsih, 2015, Pendidikan Kewirausahaan di Perguruan Tinggi, Jurnal Economia, , Vol. 11, No. 1.

Titik Purwinarti, 2006, Faktor Pendorong Minat Berwirausaha (Studi lapangan terhadapPoliteknik Negeri Jakarta), Jurnal Penelitian Ekonomi dan Bisnis, Vol. 5. No. 1.

Winarno, 2011, Pengembangan Sikap

Entreprenurship dan Intrapreneurship, Jakarta: PT. Indeks.

Yang, Jianfeng. 2013, The Theory of Planned Behavior and Prediction of Entrepreneurial Intention Among Chinese Undergraduates. Scientific Journal Publishers Ltd, V. 41. N. 3.

Zain, Z. M. Amalina Mohd Akram, Erlane K Ghani, 2010, Entreprenurial Intention Among Malaysian Business Students, Canadian Social Science, Vol. 6. No. 3. 